\title{
MATHEMATICAL MODEL OF RESOURCE-SAVING PRODUCTION TECHNOLOGY OF BAKED GOODS WITH AMARANTH FLOUR
}

\author{
ANASTASIA SHISHKIN ${ }^{1}$, MADINA SADYGOVA* ${ }^{* 1}$, MARIA BELOVA ${ }^{1}$, \\ TATYANA KIRILLOVA ${ }^{1}$
}

${ }^{1}$ Saratov State Agrarian University, 410005, Saratov, Sokolovaya Str, 335, Russia

\begin{abstract}
Amaranth is a promising raw ingredients enriching bakery products, in the work used grade "Flight" Saratov breeding. The article discusses the effect of amaranth flour and the type of liquid that goes into the dough baking on the baking properties of the semi-finished product and the quality of the finished products from wheat flour with a satisfactory quality gluten. The moisture, acidity, porosity, structural and mechanical properties, gas-forming ability, lift and fermentation activity were investigated. For the manufacture of comparable samples used wheat flour, presented on the market of Saratov. Amaranth seeds of the variety "Flight" in the amount of 7, 10, 15 and $20 \%$. Analysis of the effect of amaranth flour on the structural and mechanical properties of the dough showed that adding $7 \%$ or more of amaranth flour significantly reduces the spreading of the dough. The index of fermentation activity of semi-finished products with the share of amaranth flour $20 \%, 15 \%, 10 \%$ and $7 \%$ was significantly higher than the control, at the beginning of fermentation. The introduction of amaranth flour in an amount of 7 to $20 \%$ had a significant impact on the gas-forming ability of the wheat-amaranth dough and was characterized by an intense, "explosive" beginning of fermentation and a fairly rapid decline in fermentation intensity over time, especially in a sample with a share of amaranth flour $7 \%$. Kneading on goat milk whey had a positive effect on the studied parameters. According to the research results, the expediency of using flour from amaranth variety Flying in the technology of bakery products made from wheat flour with a satisfactory weak gluten in quality to give them functional properties has been proved. Based on the mathematical model, the optimal parameters of the process are determined: the amount of amaranth flour in the recipe for buns is $15 \%$, fermentation time 85 min, dough kneading liquid - goat milk serum.
\end{abstract}

Keywords: amaranth seeds, flour, structural-mechanical properties, fermentation activity, gas-forming ability, Pareto-optimal solutions, multicriteria optimization, bakery product

\section{INTRODUCTION}

The most important task facing the baking industry is to obtain high-quality products at low production costs, using safe quality regional raw materials and resource-saving technologies.

Domestic researchers are particularly interested in the products of the processing of amaranth seeds, because Amaranth seeds contain squalene, as well as phospholipids necessary for humans and the most useful types of vitamin E [1-8].

\footnotetext{
* Corresponding author, email: sadigova.madina@yandex.ru

(C) 2020 Alma Mater Publishing House
} 
In 2006, the breeders of grain breeding amaranth "Flight" were bred by the plant breeders at the Federal State Budgetary Institution of the Russian NIPTI of Sorgo and Maize. The yield of seeds 1.86-24.7 t / ha. The mass of 1000 seeds is $0.3-0.4 \mathrm{~g}$. Plant height before harvesting is $153-169 \mathrm{~cm}$. The duration of the periods: from sowing to germination 8-11 days, from germination to sprouting 52-58 days, from germination to first mowing 82-89 days, from sprouting to maturation 60-62 days, from germination to maturity $112-117$ days. Resistance to soil and air drought: from germination to panning 4.3 points, from panning to maturity 5.0 points. Resistance against spring and autumn frosts 5.0 points. The defeat of root rot and leaf spot is 3-5\%. In some years, damage was noted by a meadow moth $2-5 \%$ [9].

Nutrient content in aboveground biomass (dry matter): crude protein - $13.9 \%$, fiber - $19.2 \%$, nitrogen-free extractives $-41.4 \%$, sugar $-6.6 \%$. Digestibility of dry matter (in vitro) $73.8 \%$. Amaranth Grade The flight has been approved for use in all regions of the Russian Federation since 2009. Technological properties of processed products of this variety have not been studied [9].

\section{EXPERIMENTAL SETUP}

In the investigations, amaranth flour from seeds of the "Flying" variety, wheat baking flour of the premium grade of the "Ruble saves" trademark (GOST R 52189-2003) was used.

Amaranth seeds, pre-cleaned of impurities, were air-sifted, washed in a washing machine and dried on a vibrating screen, and ground in a Brabender Junior laboratory mill [10].

The effect of the dosage of amaranth flour in a composite mixture, such as liquid, used for dough kneading, fermentation time on the structural and mechanical properties of the dough, gas generating ability, fermentation activity and lift, as well as acidity, humidity, porosity, and organoleptic properties of the finished products was studied.

The gas-forming ability of the flour was determined by the volumetric method on the Iago-Ostrovsky device. Structural and mechanical properties of the semi-finished product was determined by the spreading of the dough ball. Lifting force was determined by the ascent of the ball semi-finished product. Fermentation activity at the height of the rise of the semi-finished product.

Comprehensive assessment of the quality of products was determined by a 100-point system, taking into account the coefficients of significance according to the following organoleptic indicators: porosity, elasticity, crumb color, color of the crust, taste, aroma, chewiness (Table 1) [11].

Table 1. Values of significance coefficients for indicators.

\begin{tabular}{|l|c|c|c|c|c|c|c|}
\hline Indicator & Porosity & Elasticity & Crumb Color & Peel Color & Taste & Aroma & Chew \\
\hline Score, points & $\leq 5.0$ & $\leq 5.0$ & $\leq 5.0$ & $\leq 5.0$ & $\leq 5.0$ & $\leq 5.0$ & $\leq 5.0$ \\
\hline $\begin{array}{l}\text { Significance } \\
\text { coefficient }\end{array}$ & 3.5 & 1.5 & 3.5 & 3.5 & 3.5 & 3.5 & 1 \\
\hline
\end{tabular}

Quantitative assessment of the effect of the dosage of amaranth flour in the composite mixture, the type of liquid that goes into the dough, the fermentation duration was carried out using mathematical models.

For an adequate mathematical description of the response surface in the experimental region, we apply a segment of the Taylor series with nonlinear terms.

$$
f(x, y)=\sum_{\infty}^{k=0} \frac{T^{k} f\left(x_{0}, y_{0}\right)}{k !}
$$

where $T=\left(x-x_{0}\right) \frac{\partial}{\partial x}+\left(y-y_{0}\right) \frac{\partial}{\partial y}$ differential operator.

Taking into account the difference in the type of liquid that goes into the dough mix "water" / "whey from cow's milk"/"whey from goat milk" when building a model, we will produce by introducing binary dummy variables (Table 2) [12]. 
Table 2. Replacement of the quality parameter with binary variables.

\begin{tabular}{|l|c|c|}
\hline \multirow{2}{*}{$\begin{array}{c}\text { The type of liquid that goes into the } \\
\text { dough }\end{array}$} & $v_{1}$ & $v_{2}$ \\
\cline { 2 - 3 } & 0 & 0 \\
\hline aqua & 0 & 1 \\
\hline cow milk whey & 1 & 0 \\
\hline goat milk whey & & Binary variables \\
\hline
\end{tabular}

\section{RESULTS AND DISCUSSION}

The response function for the test lift height is represented by the dependency, (Figure 1) [13]:

$$
z_{1}=a_{0}+a_{1}(x-10)+a_{2}(y-80)+a_{3}(y-80)^{2}+a_{4}(y-80)^{3}+a_{5} v_{1}+a_{6} v_{2}
$$

where $\mathrm{x}$ is the dosage of amaranth flour, $\mathrm{t}$ is the time of fermentation of the dough, binary variables "Type of liquid going to the dough", $\mathrm{a}_{0}=63.90, \mathrm{a}_{1}=0.34, \mathrm{a}_{2}=0.38, \mathrm{a}_{3}=-0.003, \mathrm{a}_{4}=-2 \mathrm{E}-0.5, \mathrm{a}_{5}=0.82, \mathrm{a}_{6}=-10.05$. Multiple correlation coefficient $\mathrm{R}=0.905$.

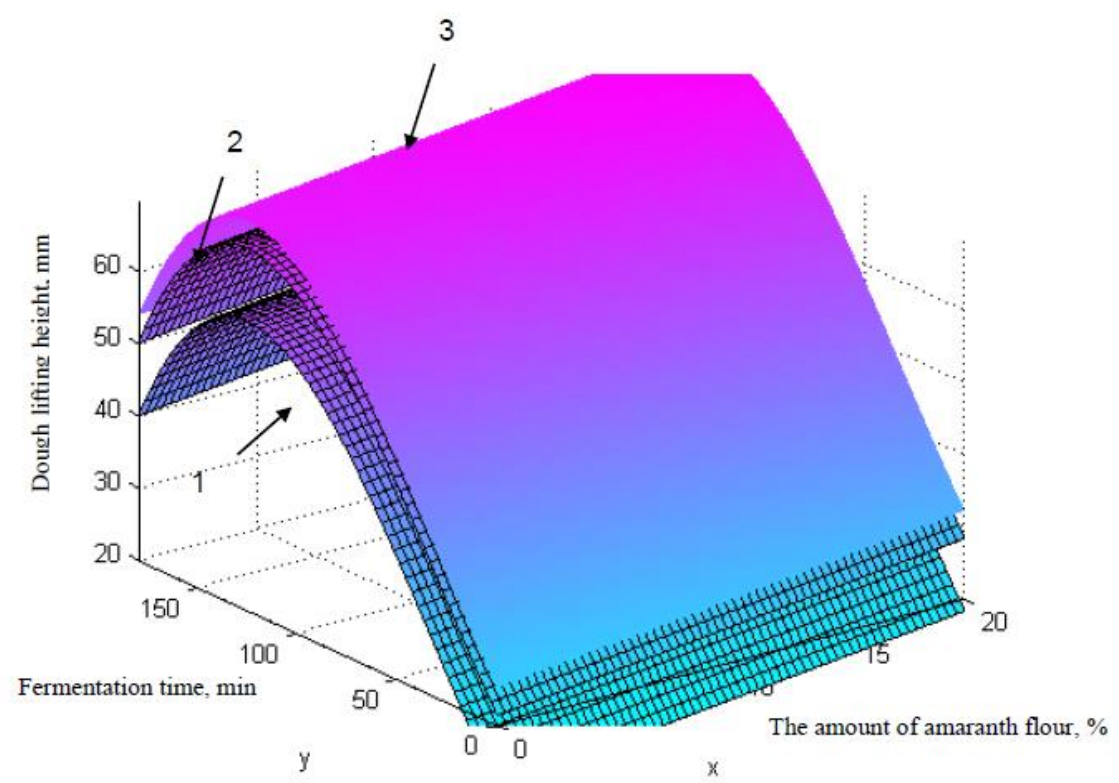

Fig. 1. Response surface for the height of the dough: 1 - a traditional batch; 2 - a batch on whey from cow's milk; 3 - a batch on whey from goat milk.

The spreading of the dough ball slows down over time. Processes with decaying growth are well described by a sigmoid curve [14].

$$
z=A+\frac{1}{a_{0}+a_{1} e^{-t}}
$$

To take into account the effect of the dosage of amaranth on the diameter of the test ball, we introduce the equation of the second variable (Figure 2):

$$
z_{2}=A+\frac{1}{a_{0}+a_{1} x^{2}+a_{2} e^{-t}}
$$

where $\mathrm{x}$ is the dosage of amaranth flour, $\mathrm{t}$ is the time of fermentation of the dough, $\mathrm{a}_{0}=0.0627, \mathrm{a}_{1}=0.0001, \mathrm{a}_{2}=$ $0.9124, \mathrm{~A}=59$. Multiple correlation coefficient $\mathrm{R}=0.839$.

After linearization, the equation takes the form: 


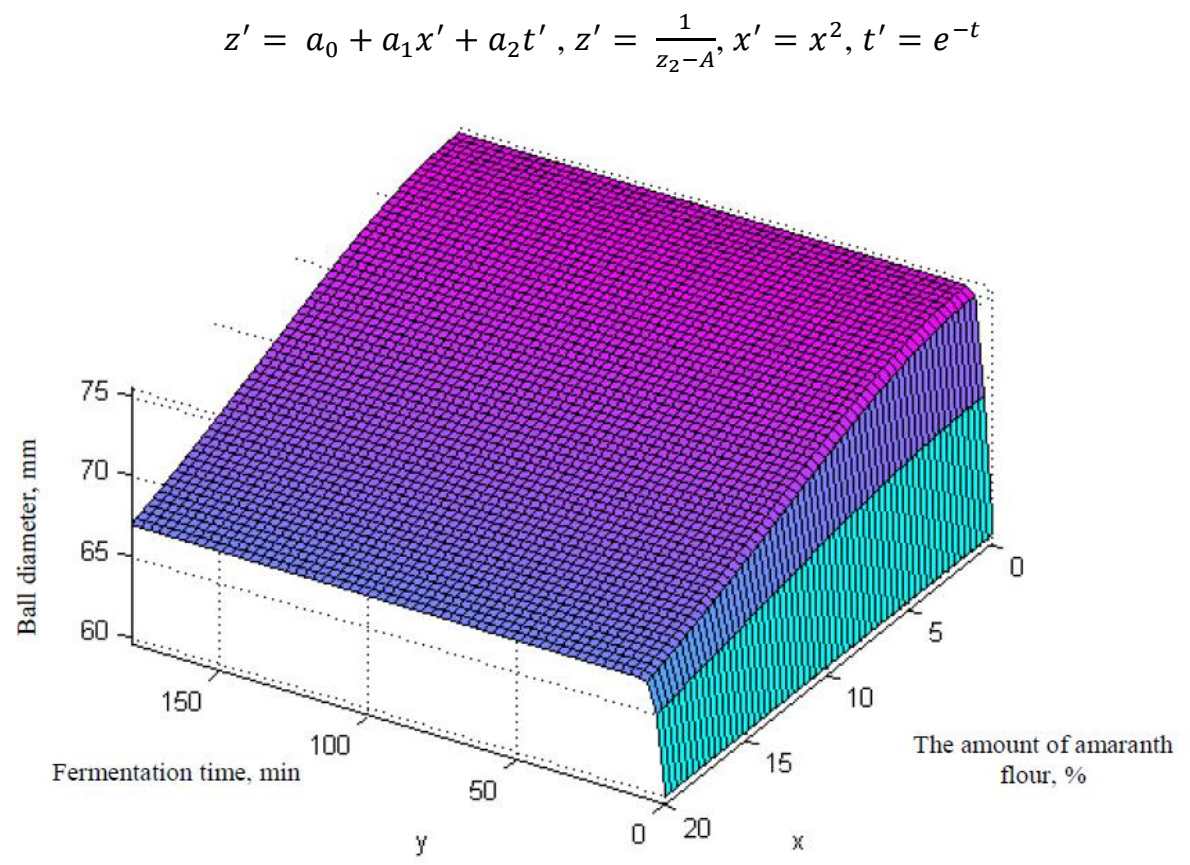

Fig. 2. Response surface for the ball diameter.

The response function for the ball ascend time is represented by the dependency (Figure 3) [14]:

$$
z_{3}=a_{0}+a_{1}(y-80)+a_{2}(x-10)(y-80)+a_{3}(y-80)^{2}+a_{4} v_{1} x+a_{5} v_{2} x+a_{6} v_{1} y+a_{7} v_{2} y
$$

where $\mathrm{x}$ is the dosage of amaranth flour, $\mathrm{t}$ is the time of fermentation of the dough, binary variables "Type of liquid going to the dough", $\mathrm{a}_{0}=8.0506, \mathrm{a}_{1}=-0.0339, \mathrm{a}_{2}=0.0029, \mathrm{a}_{3}=0.0011, \mathrm{a}_{4}=-0.3358, \mathrm{a}_{5}=-0.2528, \mathrm{a}_{6}=-0.0249, \mathrm{a}_{7}=-$ 0.03078 . Multiple correlation coefficient $\mathrm{R}=0.913$.

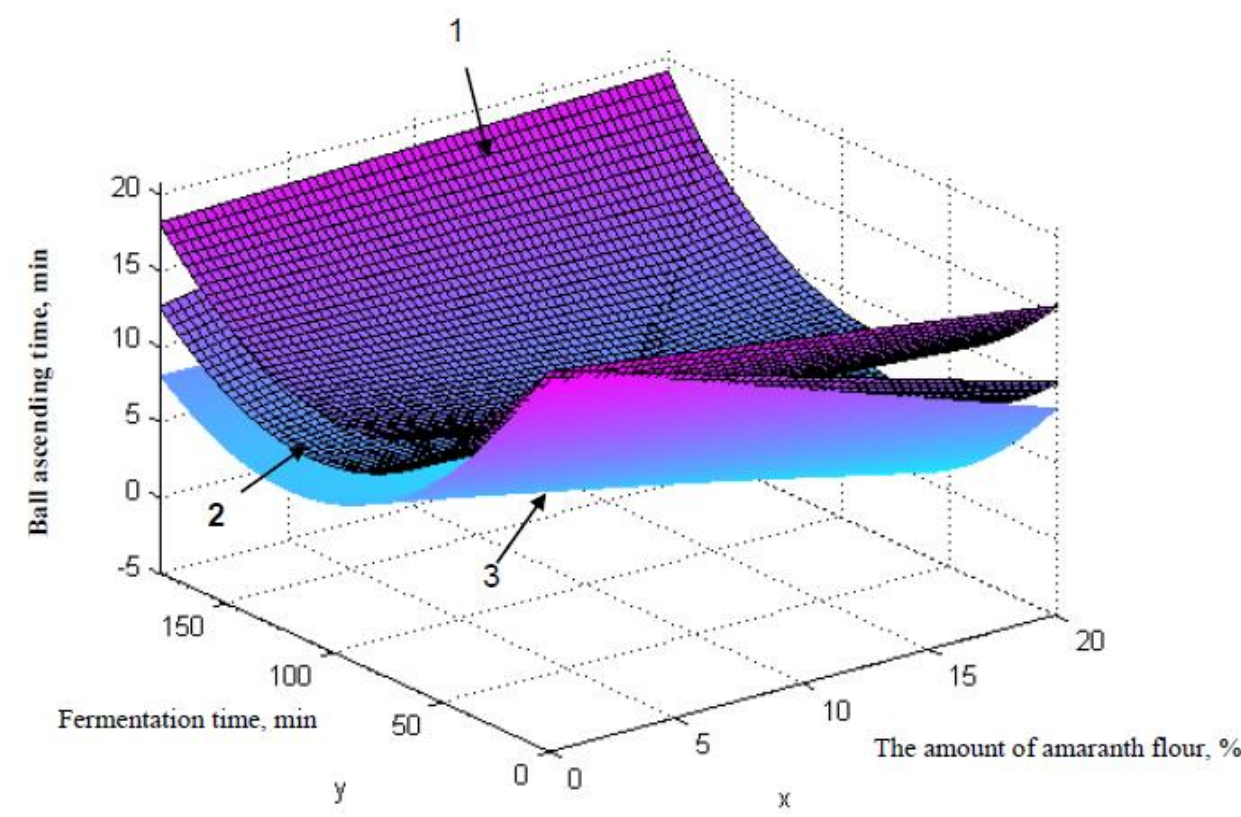

Fig. 3. Response surface for the ball ascending time: 1 - traditional kneading; 2 - kneading on cow's milk whey; 3 - kneading on goat milk whey.

The response function for the amount of released carbon dioxide (Figure 4), is represented by the dependence [15]: 


$$
z_{4}=a_{0}+a_{1}(x-10)+a_{2}(y-80)+a_{3}(x-10)(y-80)+a_{4}(y-80)^{2}
$$

where $\mathrm{x}$ is the dosage of amaranth flour, $\mathrm{t}$ is the time of fermentation of the dough, binary variables "Type of liquid going to the dough", $\mathrm{a}_{0}=691.429, \mathrm{a}_{1}=31.5529, \mathrm{a}_{2}=7.18730, \mathrm{a}_{3}=0.3043, \mathrm{a}_{4}=-0.0126$. Multiple correlation coefficient $\mathrm{R}=0.9842$.

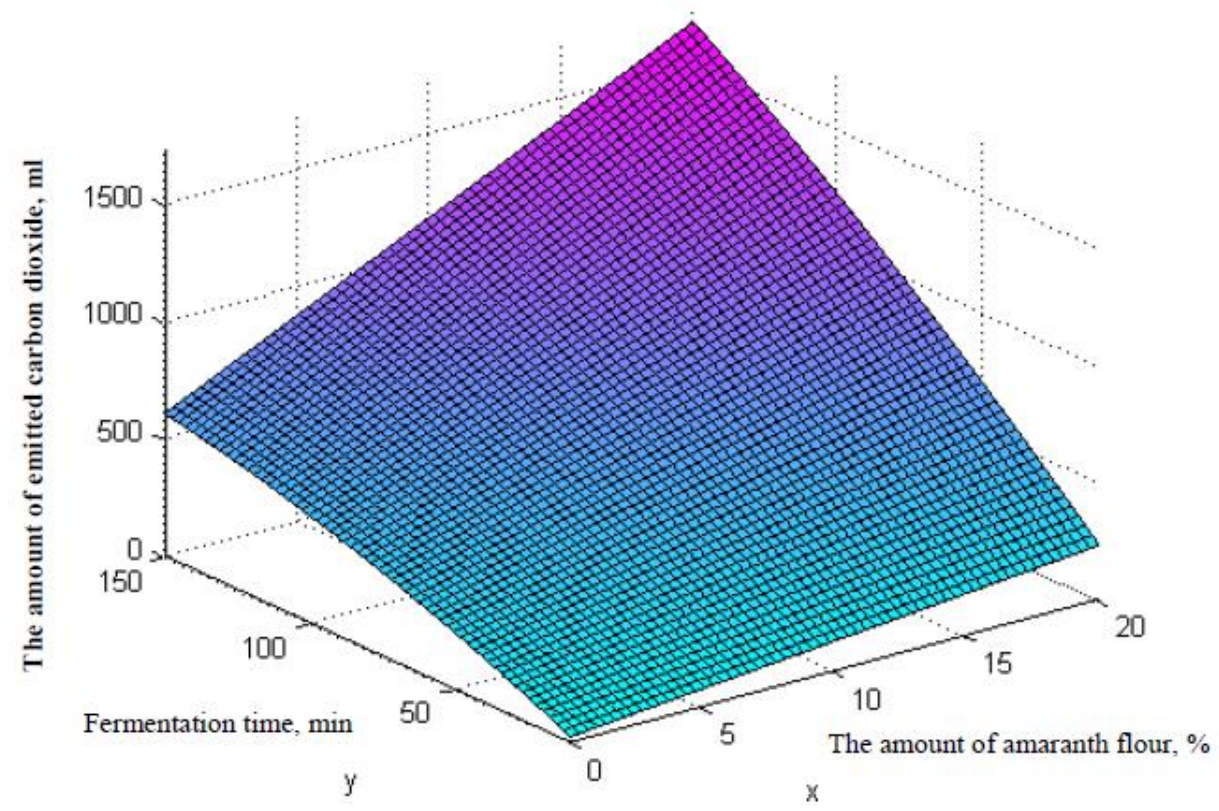

Fig. 4. Surface response for the amount of released carbon dioxide.

The response function for humidity (Figure 5) is represented by the dependency [16]:

$$
z_{5}=a_{0}+a_{1}(x-10)^{2}+a_{2} v_{1} x+a_{3} v_{2} x+a_{4} v_{1} y+a_{5} v_{2} y
$$

where $\mathrm{x}$ is the dosage of amaranth flour, $\mathrm{t}$ is the time of fermentation of the dough, binary variables "Type of liquid going to the dough", $\mathrm{a}_{0}=38.5183, \mathrm{a}_{1}=0.0173, \mathrm{a}_{2}=-0.0440, \mathrm{a}_{3}=0.2338, \mathrm{a}_{4}=-0.0068, \mathrm{a}_{5}=-0.0044$. Multiple correlation coefficient $\mathrm{R}=0.9841$.

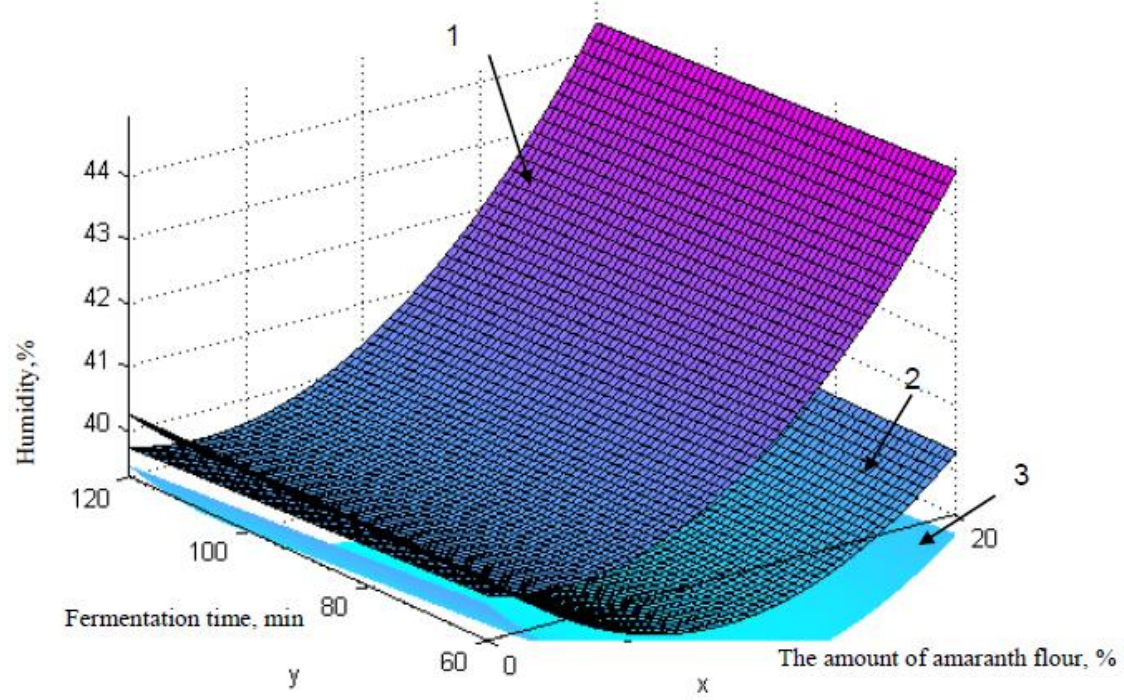

Fig. 5. Response surface for humidity: 1 - traditional batch; 2 - batch on cow's milk whey; 3 - batch on goat milk whey. 
The response function for porosity (Figure 6) is represented by the dependency:

$$
z_{6}=a_{0}+a_{1}(x-10)^{2}+a_{2}(x-10)^{3}(y-90)+a_{3} v_{1}+a_{4} v_{2}
$$

where $\mathrm{x}$ is the dosage of amaranth flour, $\mathrm{t}$ is the time of fermentation of the dough, binary variables "Type of liquid going to the dough", $\mathrm{a}_{0}=64.4866, \mathrm{a}_{1}=-0.1433, \mathrm{a}_{2}=-9 \mathrm{E}-05, \mathrm{a}_{3}=3.1667, \mathrm{a}_{4}=1.8867$. Multiple correlation coefficient $\mathrm{R}=0.8471$.

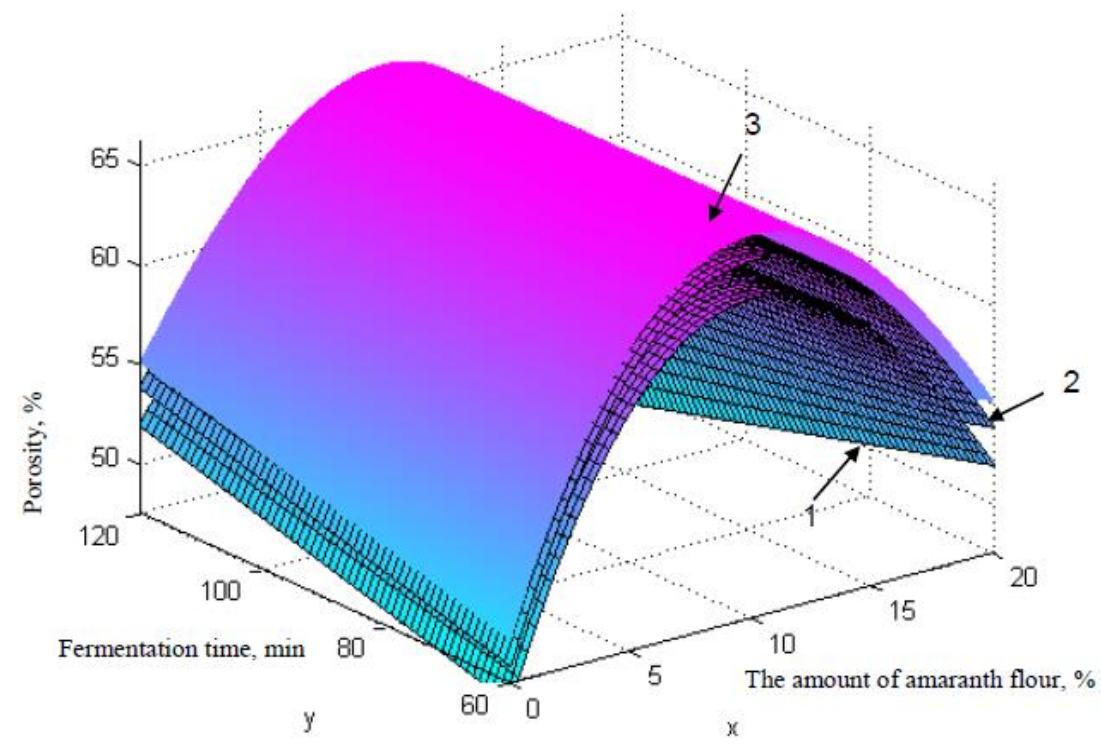

Fig. 6. Response surface for the porosity of the finished product: 1 - a traditional batch; 2 - a batch on cow's milk whey; 3 - a batch on goat milk whey.

The response function for acidity (Figure 7) is represented by the dependency [17]:

$$
z_{7}=a_{0}+a_{1} x+a_{2} y+a_{3} v_{1}+a_{4} v_{2}
$$

where $\mathrm{x}$ is the dosage of amaranth flour, $\mathrm{t}$ is the time of fermentation of the dough, binary variables "Type of liquid going to the dough", $\mathrm{a}_{0}=1.7207, \mathrm{a}_{1}=0.0649, \mathrm{a}_{2}=0.0012, \mathrm{a}_{3}=1.0000, \mathrm{a}_{4}=0.7466$. Multiple correlation coefficient $\mathrm{R}=0.9461$.

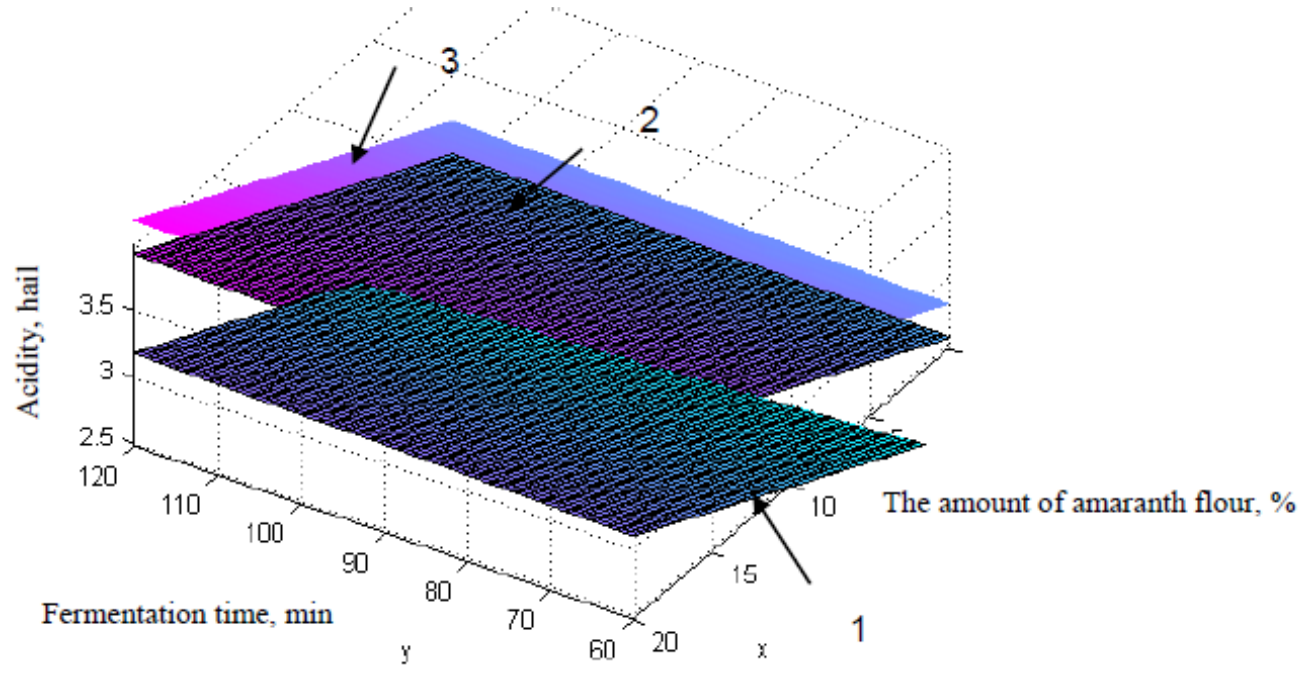

Fig. 7. Response surface for the acidity of the finished product: 1 - traditional batch; 2 - batch on cow's milk whey; 3 - batch on goat milk whey. 
The response function for the score is represented by the dependency (Figure 8):

$$
\begin{aligned}
& z_{8}=a_{0}+a_{1}(x-10)+a_{2}(x-10)^{2}+a_{3}(y-90)+a_{4}(x-10)(y-90)+a_{5} v_{1} x+a_{6} v_{2} x+ \\
& a_{7} v_{1} y+a_{8} v_{2} y
\end{aligned}
$$

where $\mathrm{x}$ is the dosage of amaranth flour, $\mathrm{t}$ is the time of fermentation of the dough, binary variables "Type of liquid going to the dough", $\mathrm{a}_{0}=96.9421, \mathrm{a}_{1}=-0.1948, \mathrm{a}_{2}=-00.0256, \mathrm{a}_{3}=0.0153, \mathrm{a}_{4}=-0.0037, \mathrm{a}_{5}=0.0002, \mathrm{a}_{6}=4.25 \mathrm{E}-05$, $\mathrm{a}_{7}=9.16 \mathrm{E}-05, \mathrm{a}_{8}=7.35 \mathrm{E}-05$. Multiple correlation coefficient $\mathrm{R}=0.8332$.

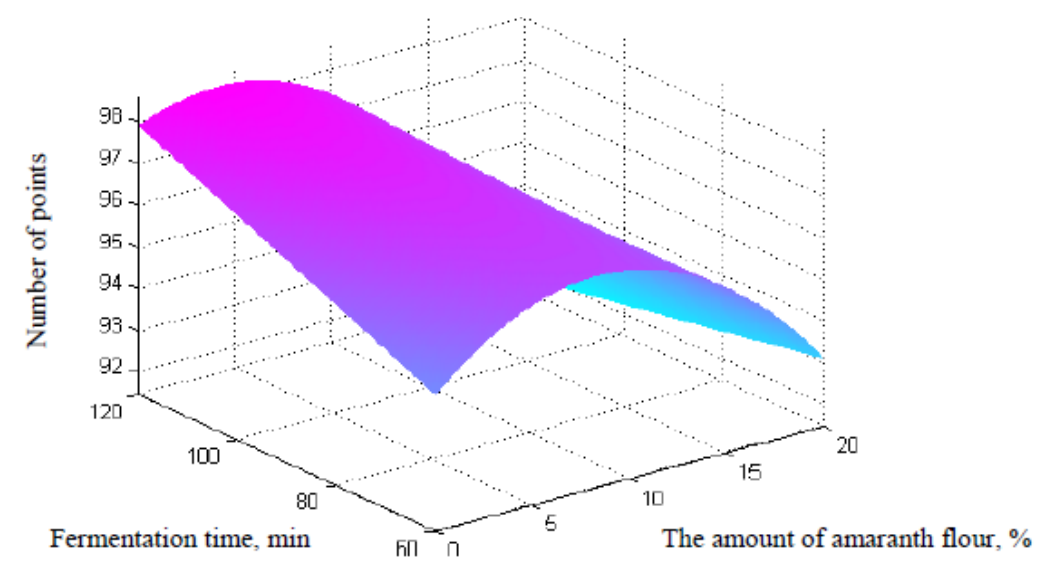

Fig. 8. The results of the point estimates depending on the content of amaranth flour and time of fermentation.

To determine the optimal dosage of amaranth flour, fermentation time, liquid, which goes to the dough in the formulation of products with the addition of amaranth flour, we construct a mathematical optimization model using five criteria (11) - (12):

$z_{1}\left(x, y, v_{1}, v_{2}\right) \rightarrow \max ; z_{2}\left(x, y, v_{1}, v_{2}\right) \rightarrow \min ; z_{3}\left(x, y, v_{1}, v_{2}\right) \rightarrow \min ; \frac{\partial z_{4}\left(x, y, v_{1}, v_{2}\right)}{\partial_{t}} \rightarrow \max ; z_{8}\left(x, y, v_{1}, v_{2}\right) \rightarrow$ $\max$

$$
\left\{\begin{array}{c}
z_{5}\left(x, y, v_{1}, v_{2}\right) \leq 42 \\
z_{6}\left(x, y, v_{1}, v_{2}\right) \geq 60 \\
z_{7}\left(x, y, v_{1}, v_{2}\right) \leq 4 \\
0 \leq x \leq 20, \quad 60 \leq y \leq 120
\end{array}\right.
$$

where $v_{1}, v_{2}$ is binary dummy variables.

In a multicriteria problem with competing criteria, a solution that is more preferable by one criterion is less preferable by another criterion. The optimal plans for such a task are in the area of compromises - Pareto optimal solutions.

To obtain the Pareto-optimal solution vector using the guaranteed result method, we transform the multicriteria task into a single-criterion (13) - (14):

$$
\begin{gathered}
z=y \rightarrow \max \\
\left\{\begin{array}{c}
\lambda \leq \lambda_{k}\left(x, y, v_{1}, v_{2}\right), k=1,2, \ldots, 4 \\
\lambda \leq \lambda_{8}\left(x, y, v_{1}, v_{2}\right) \\
z_{5}\left(x, y, v_{1}, v_{2}\right) \leq 42 \\
z_{6}\left(x, y, v_{1}, v_{2}\right) \geq 60 \\
z_{7}\left(x, y, v_{1}, v_{2}\right) \leq 4 \\
0 \leq x \leq 20, \quad 60 \leq y \leq 120
\end{array}\right.
\end{gathered}
$$


where: $\lambda_{k}\left(x, y, v_{1}, v_{2}\right)=\frac{z_{k}\left(x, y, v_{1}, v_{2}\right)}{z_{k}^{*}}, z_{k}^{*}=\max _{x, y, v_{1}, v_{2} \in D} z_{k}\left(x, y, v_{1}, v_{2}\right)$.

The results of solving problems (11) - (12) and (13) - (14) are presented in Table 3.

Table 3. The results of solving optimization problems.

\begin{tabular}{|c|c|c|c|}
\hline $\begin{array}{c}\text { The value of the criterion on the } \\
\text { optimal plan }\end{array}$ & $\begin{array}{c}\text { mass fraction amaranth flour } \\
(\%)\end{array}$ & $\begin{array}{c}\text { fermentation time } \\
(\mathrm{min})\end{array}$ & Dough kneading liquid \\
\hline$z_{1}^{*}=68.56661$ & 16.38 & 105.03 & Goat milk whey \\
\hline$z_{2}^{*}=69.10795$ & 15.65 & 100.03 & Goat milk whey \\
\hline$z_{3}^{*}=0.7992$ & 17.54 & 75.03 & Goat milk whey \\
\hline$z_{4}^{*}=8.56479$ & 16.34 & 85.73 & Goat milk whey \\
\hline$z_{8}^{*}=97.35174$ & 16.99 & 101.76 & Goat milk whey \\
\hline$\lambda=0.901568$ & 15 & 85 & Goat milk whey \\
\hline
\end{tabular}

The optimal solution of the single-criterion problem (13) - (14) is the point $x=15, y=85, v_{1}=1, v_{2}=0.4$.

\section{CONCLUSIONS}

As a result of the research, we can draw the following conclusions: the introduction of amaranth flour into the bakery product formulation affects the physicochemical and organoleptic properties of the finished products, as well as the fermentation activity, the gas-forming ability and the structural and mechanical properties of semifinished products. Based on the regression model, the content of $15 \%$ amaranth flour in the recipe of a bakery product instead of wheat flour was optimized according to the output parameters; fermentation duration - 85 min. The optimal method of dough preparation is determined - on goat serum.

\section{REFERENCES}

[1] Ashilkhanov, A.S., Smolnikova, F.Kh., Application of dairy whey in bakery, Collected materials of the International Scientific and Technical Conference, Innovative Technologies in The Food Industry: Science, Education and Production, 2013, p. 69-72.

[2] Grishina, E.S., Gavrilova, N.B., Konovalov, S.A., Production of bakery goods using dairy products (review of literature), Bulletin of the Omsk State Agrarian University, vol. 4, no. 16, 2014, p. 45-48.

[3] Berry, D., Prospects for the use of dairy ingredients, Confectionery and bakery, 2010, vol. 2, p. 6-7.

[4] Grishina, E.S., Gavrilova, N.B., Konovalov, S.A., Improving the biotechnology of bakery products, Bulletin of the Altai Science, vol. 1, 2015, p. 359-363.

[5] Shishkina, A.N., Sadigova, M.K., Belova, M.V., Larin, Yu.N., Astashov, A.N., Biotechnological properties of a wheaten semi-finished product with addition of amarantovy flour, XXI century: results of the past and problem of the present plus, vol. 3, no. 43, 2018, p. 49-53.

[6] Zueva, E.A., Sluginova, N.I., Sarafankina, E.A., On the prospects of using whole-hulled amaranth flour in the production of wheat bread, XXI Century: the Results of the Past and the Problems of the Present Plus, vol. 1, no. 35, 2017, p. 37-40.

[7] Tertychnaya, T.N., Manzhesov, V.I., Mazhulina, I.V., Kalashnikova, S.V., Modern technologies of bakery production: textbook, Voronezh: FGBOU Voronezh State University of Automated Control, 2018, p. 189.

[8] Paschenko, L.P., Zharkova, I.M., Technology of bakery production, SPB Publishing House Lan, 2014, p. 672.

[9] Zhuzhukin, V.I., Shor, M.F., New varieties of amaranth, Bulletin of the Botanical Garden of Saratov State University, vol. 9, 2010, p. 80-84.

[10] Açu, M., Kinik, Ö., Yerlikaya, O., Functional properties of the probiotic ice cream prepared from goat's milk, Carpathian Journal of Food Science and Technology, vol. 9, no. 4, 2017, p. 86-100.

[11] Manjula, K., Bhagath, Y.B., New generation functional foods-A prospectus on processing technology assistance in development and production-A Review, Carpathian Journal of Food Science and Technology, vol. 9, no. 2, 2017, p. 64-76.

[12] Krasulya, O.N., Nikolaev, S.V., Tokarev, A.V., Simulation of food formulations and their production technologies: theory and practice: studies, GIORD, 2015, p. 320.

[13] Korolev, A.L., Computer modelling. Laboratory Workshop, BINOM, Laboratory of knowledge, 2012, p. 296. 
[14] Horns, I.A., Rogov, I.A., Bobreneva, I.V., Nikolaev, S.V., Mathematical modeling in technologies of healthy food products: a tutorial, MGUPB, 2009, p. 124.

[15] Nikolaev, S.V., Pverin, A.D., Tyrsin, Yu. A., Optimization of mixing processes of multicomponent functional foods, Biotechnology, 2009, p. 70.

[16] Korolev, I.A., Computer modeling, BINOM, Laboratory of Knowledge, 2010, p. 320.

[17] Nikolaev, S.V., Analysis, management and automated processing of estimates of the quality indicators of products, Sputnik +, 2011, p. 84 . 